\title{
THE JUDICIAL SYSTEM OF THE BRITISH COLONIES.
}

The consolidation in $x$ gor of the six Australian colonies into a federation of states known as the "Commonwealth of Australia" and the establishment of a political and judicial system in that Commonwealth modeled in its chief provisions upon the Constitution of the United States has given students of politics a fresh opportunity for the observation in practice of the principle of federation, and should stimulate all who are interested in the study of comparative governments to an examination not only of the workings of the Australian Commonwealth, but also of the political and the judicial structures of the other important British colonies throughout the world.

To the lawyer, especially to the lawyer who is ambitious eventually to become a jurist, a study of the judicial system of all governments administering the common law and civil law is of inestimable advantage. Moreover, a knowledge of the institutions of other countries is at once interesting in itself and broadening to the student who has the patience to search for and to acquire the information.

In England the great body of rules which we know as the common law was developed; from England this body of common law has been carried to most of the colonies which England has founded or conquered, and it is today administered by judges who are following substantially the same precedents as obtain in the courts of the mother country and of the United States.

It is interesting to consider the wisdom of English statesmen in imposing a system of law upon a colony. In such colonies, for example, as the Australasian colonies where an inconsiderable aboriginal population was found and where no formal code of law acceptable to Englishmen prevailed the common law was introduced. In other colonies which had been under the governmental control of European countries where the civil law was in force, such as British Guiana, Cape Colony, Ceylon, Mauritius and Quebec, England upon taking possession deemed it wise and necessary to continue and to maintain the existing 
code of law. We find, therefore, that in a number of the British colonies the civil law prevails,-either the civil law based upon the Code Napoleon, as in Quebec and Mauritius, or the civil law as modified and interpreted by the Dutch jurists and known to students of comparative jurisprudence as the RomanDutch law.

In the Commonwealth of Australia and in the several States which compose that Commonwealth the common law obtains with no admixture of native laws and customs. But in a number of minor colonies, as well as in the British possessions in India, where there is a large or predominant native population it is necessary to recognize the usages and customs of the natives in any controversies to which the natives may be parties. In the colony of Natal in South Africa, for example, where the Roman-Dutch law was brought in by the Dutch settlers and continued by the British when they acquired Natal, that code of law still regulates the rights of the European population, but the native Zulus and other aboriginal peoples are governed by their own native laws and conventions, if reasonable, and in civil and criminal cases arising out of native customs they are judged, so far as it is possible and proper, by their own tribal rules and usages. In the main, however, the British colonies can be divided into the colonies administering the common law and those administering the civil law. The colonies in which the common law obtains are the more numerous and the more important. Indeed in the colonies where the civil law prevails the civil law has been in many instances modified by the courts and by colonial acts and ordinances in the direction of common law rules.

This condition is best illustrated by citing the colony of Ceylon. Ceylon though known to the Greeks, the Romans and the Venetians, was settled by the Portugese, who were subsequently dispossessed by the Dutch. As the civil law was the law of the Netherlands, the Dutch conquerors imposed their own system upon Ceylon. When the English took over Ceylon in 1795, they very wisely permitted the pre-existing code to continue. The tendency of the English judges, however, is towards the common law, and for that reason the system of law prevailing in Ceylon where the judges of the highest court are and have been mainly English is a kind of composite of the common law and the civil law with some admixture of native law and customs. The well known Indian Penal Code framed by Lord Macaulay has furnished the foundation for the Ceylon Penal 
Code. Codes of civil and criminal procedure based upon the Indian codes are now in force in Ceylon as well.

The Constitution of the Australian Commonwealth, as has been said, was based in broad outline upon the Constitution of the United States. The Commonwealth of Australia is a federation of colonies which, before the federation, were for all practical purposes autonomous. The Constitution of the Commonwealth is an act of the Imperial Parliament in England, but it is amendable by the Australians themselves without the necessity of applying to the British Parliament for permission to amend. A nominal right of approval of any amendment is, however, reserved to the Crown.

The Constitution provides for the creation of a court to be known as the High Court of Australia and of such inferior courts as the Parliament of the Commonwealth may deem necessary or proper to establish. In other words, the Commonwealth can create a complete judicial system of its own, just as Congress has done in the United States. Up to the present time, however, the Commonwealth Parliament has seen fit to establish only the High Court consisting of three judges and to grant to the judges of the State courts, in addition to their powers as State judges, jurisdiction in federal matters. As the Commonwealth increases in population a complete federal judiciary will undoubtedly be created.

The annual salary of the Chief Justice of the High Court of Australia, it may be well to add, is $\$ 17,500$ and that of each of the other justices is $\$ 15,000$.

Each component State in the Commonwealth has of course its own judicial system comprising a Supreme Court and subordinate courts. The number of the judges of the Supreme Court varies with the size and the importance of the State, but in every State the judges of the Supreme Court hold trial sittings as well as appellate sittings and they have jurisdiction both at law and in equity.

The plan prevailing in Australia, where judges of the State cuurts do trial and appellate work, obtains in most of the British colonies. There are courts in the British colonies, such as the Supreme Court of Canada, the judges of which conduct no trials, but the general rule, for reasons of economy in administration, is that all British colonial judges of the Supreme Court shall hold trial sessions of court and shall collectively hear appeals. It need hardly be added that no judge hears an appeal from a trial court of which he was the presiding judge. In at least one 
American State (Vermont) the practice prevailing in the British colonies is still observed. Other American States, like New Hampshire, where this practice was once observed, have either modified their judicial systems to conform to present-day needs, or have completely changed them to the systems in force in $\mathrm{New}$ York and Massachusetts.

The salaries of the judges in the Commonwealth of Australia are somewhat higher than the salaries which the judges in the United States usually receive. The Chief Justice of the State of New South Wales receives the same salary as does the Chief Justice of the High Court of Australia, $\$ 17,500$, and each of the six puisne judges receives an annual salary of $\$ 15,000$. In the State of Queensland the Chief Justice of that State receives $\$ 12,500$ and each of the three puisne judges $\$ 10,000$. In Victoria the judges of the Supreme Court receive the same salaries as do the judges in New South Wales, and in the other Australian States, though the salaries of the judges are not quite so high, yet they are far higher than the average salary of an American judge of a superior court.

In Canada a somewhat anomalous condition of affairs prevails. In the United States and in Australia the federal government exercises only such powers as are expressly or impliedly granted to it by the Constitution, and such porers are subject to review by the highest court of the federation. In Canada, however, though the courts have the power to declare acts of the Dominion and the provincial parliaments unconstitutional and frequently exercise that power, yet the division of powers between the Dominion, or central government at Ottawa, and the various provinces is based upon a different theory from that upon which the constitution makers of the United States and Australia acted. The Constitutional act of 1867 , under which the Dominion is governed, specifies the powers exercisable by the central government at Ottawa and those exercisable by each of the provinces of the Dominion. It also declares in substance that in case of any doubt as to whether the Dominion or the province has the power to act the doubt shall be resolved in favor of the Dominion government and that all powers not granted to the provinces in the Constitution are reserved to the Dominion. In other words, the Canadian Constitution allows the several provinces only such powers as are granted to them in the Constitution and reserves to the federal government all the remaining powers. The Constitution of the United States and the Constitution of the Commonwealth of Australia, however, grant to the 
federal government only certain specified powers and expressly commit to each constituent State all the residue. An American State or an Australian State has plenary power through its legislature to enact any law which it may deem fitting to enact subject to the federal constitution and the constitution of the particular State.

Bearing in mind then this distinction, we can readily comprehend the Canadian polity and the difference between it and the American and the Australian.

Except for the minor courts in the several provinces of the Dominion of Canada all the judges of the Canadian courts, both provincial and federal, are appointed and paid by the Dominion government. Each province, however, may regulate the procedure and the organization of its own courts.

The highest court in the Dominion is the Supreme Court of Canada, which always sits at Ottawa and which is composed of a chief justice and of five associate justices. The annual salary of the Chief Justice is $\$ 10,000$ and that of each of his associates is $\$ 9,000$. At least two of the justices of the Supreme Court of Canada must be appointed from the bar of the French-speaking Province of Quebec.

The only other distinctly federal court is the Exchequer Court of Canada,-a court corresponding in jurisdiction to courts in the United States for the adjudication of claims against a State or the United States. The Exchequer Court of Canada and its several local divisions exercise admiralty jurisdiction as well.

The judicial system of the important Province of Ontario follows very closely, both in nomenclature and in practice, the English and the Irish court system. In the Province of Ontario the Supreme Court of Judicature consisting of a Court of Appeal and the High Court of Justice is obivously a reproduction of the English and the Irish courts bearing the same names. The Court of Appeal is composed of a chief justice and four associate justices, and it may sit in two divisions. The High Court of Justice is divided into four separate divisions; the Chancery Division, the King's Bench Division, the Common Pleas Division and the Exchequer Division. To each of these divisions three justices are attached; a chancellor and two associates in the Chancery Division, and a chief justice and two associates in each of the other divisions. Each of these divisions of the High Court has identical powers and jurisdiction, and the judges of all these divisions hold trial sessions of court both at law and in 
equity in the chief towns of the Province. The Chancery Division is not necessarily restricted to the adjudication of causes in equity.

The judges of the High Court of Justice exercise appellate jurisdiction in what are known as "Divisional Courts," another obvious imitation of the English court nomenclature. These divisional courts are usually held by a chief justice (or chancellor) and by two other judges of the High Court assigned for that purpose. From a decision of a trial session of the High Court an appeal may be taken in certain cases direct to the Court of Appeal; in other cases to the Divisional Court and thence under certain limitations to the Court of Appeal. Thence if the case be important enough an appeal may be taken to the Supreme Court of Canada or to the Judicial Committee of the Privy Council in England as the appellant may elect.

There are, of course, in Ontario, courts of lesser jurisdiction than the High Court, such as the county courts and surrogate's courts in each county of the Province. Appeals from these courts are heard in the first instance in a divisional court.

In the Province of Quebec the Superior Court is the court of highest original jurisdiction in civil cases. From this court an appeal may be taken to three judges of that court who sit as the Superior Court in Review, a court somewhat like the Appellate Division in the State of New York. From the determination of the Superior Court in Review an appeal may be taken under certain circumstances to the Court of King's Bench, appeal side, a court which sits with no more than five judges in appeal cases. From the Court of King's Bench the persistent litigant may appeal, as in Ontario, either to the Supreme Court of Canada or to the Judicial Committee of the Privy Council in England.

In the other provinces of Canada successive appeals are not allowed with so much freedom. In Nova Scotia, New Brunswick, Prince Edward Island and the other Canadian provinces the judges of the highest court of original jurisdiction, usually called the Supreme Court, try cases individually and hear appeals collectively. There are no intermediate appellate courts of superior jurisdiction in any Canadian province except in the provinces of Ontario and Quebec.

It need hardly be added that in all the provinces of Canada there are courts exercising probate jurisdiction and also courts where suits for petty debts can be brought.

From this brief survey of Australian and Canadian judicial institutions one fact is singular and somewhat anomalous, the 
fact that appeals may be taken direct from the highest State or Provincial Court to the Judicial Committee of the Privy Council without the necessity of exhausting the opportunity of appeal in the Commonwealth or Dominion. The explanation of this rather illogical right of appeal is found in the fact that before the union of the Australian colonies into the Commonwealth and the Canadian provinces into the Dominion the right to appeal to the Judicial Committee from each colony and province was allowed. After union it proved difficult to abrogate that right and therefore the right of appeal from the highest colonial and the highest provincial court to the Judicial Committee was preserved.

The common law prevails throughout the Dominion of Canada except in the Province of Quebec. In that Province, where the major portion of the population is French, the civil law based upon the Code Napoleon is in force, though that system of law has been materially modified, especially on its commercial side, by contact with English laws and customs. The civil law of Quebec has been codified and there is also in that province a Code of Civil Procedure.

The common law in the Dominion has of course been affected by statutory legislation, as in other common law countries, but though several codifying statutes relating to such subjects as banking, railways and insurance have been enacted, the common law has not been codified according to the notions of David Dudley Field and as exemplified in practice by the Civil Code of California.

Under the Constitution of Canada the Dominion Parliament has power over criminal law and procedure, and Parliament has, pursuant to that power, enacted a penal code and a criminal practice code for the entire Dominion. The inhabitants of the Province of Quebec take no exception to the right of the Dominion Parliament to formulate common law definitions of crime and to frame rules of criminal procedure. The reason for this acquiescence in the supplanting of the civil law by the common law is found in the fact that jury trials were absolutely unknown in French Canada prior to the English occupation, and the criminal law was there administered by the French, oftentimes harshly and capriciously.

In no province in Canada is a unanimous verdict of a jury required in civil cases, though the number of jurymen necessary to bring in a verdict varies in the different provinces. In criminal cases, however, the verdict of the jury must be unanimous before a defendant can be convicted. 
In England, as is generally known among lawyers, the profession of the law is divided into two classes, that of barristers and that of solicitors or attorneys. Barristers are examined for the Bar by the Council of Legal Education of the four Inns of court and are subject to discipline by the Inn by which the barrister was called to the bar. Solicitors, however, are under the jurisdiction of the Law Courts and the Incorporated Law Society, a body entirely distinct from the Inns of Court. In England only barristers have the right to appear for trial or argument before the superior courts. The barrister is the trial lawyer; the solicitor is the office lawyer, and in no possible way can a solicitor practice as a barrister unless he renounces his office as a solicitor and is called to the bar in the regular way.

In Canada, however, though practicing lapyers are usually known as barristers and solicitors (as advocates in Quebec), yet the profession is not there separated as in England and there is no distinction in practice between a barrister and a solicitor, except that in some provinces a law student is admitted first as a solicitor and subsequently as a barrister. In most of the other colonies of the Empire there is really no practical distinction between the two classes in the profession, because a solicitor, as such, is not prevented from becoming a barrister if he chooses.

India presents a rather anomalous condition of affairs to the student of judicial systems. India is not regarded as a colony of the Empire and, is therefore, not under the supervision and control of the British Colonial Office.

India is populated by many different races and by representatives of many different languages and racial customs. Though governed by a Governor-General and Council, India is not precisely a federal State nor is it a unitary State. It partakes, in fact, of the nature of both.

India is composed of a number of states ruled directly by Englishmen and a number of feudatory states ruled by native sovereigns under British direction. In several of the states of India ruled directly by Englishmen, such as the Presidencies of Bombay and Madras, there is a supreme court, or High Court, as it is technically termed, and in addition, subordinate or magistrate's courts. The Chief Justice of the High Court of a Presidency is an Englishman, but there are usually one or more natives on the bench of a High Court. These natives are generally men of a high order of ability and learning, and they make very satisfactory judges. Their knowledge of native customs is invaluable to their English colleagues. Nearly all the 
civil judges and the great majority of magistrates in the courts of original jurisdiction in India are natives.

Appeals may be taken from the High Court judge sitting at nisi prius or from the lesser courts to a divisional court or to the full bench of the High Court. Thence under certain limitations to the Judicial Committee of the Privy Council in England. There is, it is to be observed, no "Supreme Court of India."

In all courts of India where natives are parties to actions or proceedings native laws and customs, especially in family relations and in questions pertaining to inheritances, have the force of law. These customs are principally Hindu and Mohammedan usages which have been in existence in India for several hundred years. Where the native customs can play no part in the controversy or where it is not desirable that they should, English law prevails.

The criminal law of India was codified by Lord Macaulay after he went out to India in 1834 and was enacted into law in 1860. There is also a codification of the rules regulating procedure in criminal cases. The Indian Penal Code is justly regarded as one of the greatest and wisest achievements in codification, and it has, therefore, been followed in other states, notably in Ceylon and in the Straits settlements. Indian codifications of the law of evidence, contracts, negotiable instruments and several other branches of law have been successfully administered for many years.

In the native states of India the administration of justice is extremely untechnical and simple. In case of abuse of power the courts, however, are or can be supervised by the central government.

In a few of the very small and unimportant British possessions, like St. Helena and the Falkland Islands, the governor of the colony is the sole judge in the important cases. In Cyprus, an island which Great Britain occupies pursuant to a convention with Turkey made in 1878 , Ottoman law is applied by the courts in cases where the defendant or both parties are Turks. In several other colonies owing to lack of sufficient court business the judicial system is not highly organzied.

In all the British colonies, however, the judges are usually appointed for life. They have ample salaries, they are men of character, ability and learning, and they administer justice honestly, fearlessly and impartially. Moreover, the right of appeal from colonial courts to the Judicial Committee of the Privy Council in all important cases assures the litigant that his 
rights will be passed upon by judges of the highest eminence and character.

British rule in the colonies has been on the whole beneficial to the natives and satisfactory to the European residents. Great Britain's passion for efficient government has been nowhere better illustrated than in her colonies, and not the least efficient branch of her colonial administration are her courts and her judicial system.

Raymond H. Arnot. 